\title{
L1 in the EFL classroom: more a help than a hindrance?
}

\author{
Carolina Rodríguez Juárez and Gina Oxbrow \\ Departamento de Filología Moderna \\ Universidad de Las Palmas de Gran Canaria
}

Received: 12 August 2007 / Accepted: 28 September 2007

ISSN: $1697-7467$

\begin{abstract}
The use of the L1 in monolingual contexts has been somewhat frowned upon in EFL classrooms over the years, with teaching activities usually conducted exclusively in the target language. However, if used judiciously, the mother tongue may in fact become a teaching and learning resource which can greatly enhance the acquisition process and encourage learners to focus on similarities and differences between their L1 and the language under study. In the present study, we shall explore the use of L1 and translation with first-year English Language students of 'English Philology' at the University of Las Palmas de Gran Canaria, Spain.
\end{abstract}

Key words: mother tongue, translation, contrastive analysis, EFL classroom practice.

RESUMEN: El uso de la lengua materna en contextos monolingües de enseñanza del inglés como lengua extranjera ha estado a menudo mal considerado, realizándose las tareas docentes exclusivamente en la lengua meta. Sin embargo, el uso sensato de la lengua materna puede de hecho servir como un recurso de enseñanza/aprendizaje que puede mejorar los procesos de adquisición y ayudar a los alumnos a centrarse en las diferencias y similitudes entre su lengua y la lengua extranjera. En este trabajo, investigaremos el uso de la lengua materna y de la traducción en alumnos de primer curso de Filología Inglesa de la Universidad de Las Palmas de Gran Canaria, España.

Palabras clave: lengua materna, traducción, análisis contrastivo, actividades en el aula de inglés.

\section{INTRODUCTION}

The role of the mother tongue (L1) in English as a Foreign Language (EFL) teaching contexts, as well as the use of translation as a language learning/teaching resource, have long been the subject of much controversy and academic debate in both Second Language Acquisition (SLA) research literature and professional teaching spheres, reflecting the constant fluctuations in language learning theory that have subsequently led to differing methodological prescriptions for classroom practice. ${ }^{1}$ Originally, translation featured as the central axis of pedagogical

${ }^{1}$ A clear example of this is the learning versus acquisition debate, or the role of conscious contemplation of grammatical structures as opposed to informal learning (e.g. Krashen, 1988). 
procedure in the earliest described foreign language teaching methodology, the well-known 'Grammar Translation' method (Richards and Rogers, 2001:5-7), but explicit translating was later eliminated from recommended teaching practice as the 'Direct Method' (ibid::11-14), with its strictly enforced policy of banning the use of the mother tongue from teaching contexts, gained popularity towards the end of the nineteenth century. Since then, the learner's first language has maintained a rather low profile in EFL classrooms, periodically reappearing as a pedagogical resource that often seems to produce a certain amount of unease on the part of both teachers and learners, all too aware of the alleged crucial importance of a monolingual orthodoxy and maximum contextualised language use for acquisition purposes.

This negative attitude associated with L1 use is certainly true in our current learnercentred climate, where instructional attempts to help develop foreign language skills are focused on the fostering of a supportive communicative learning/teaching context replete with valuable 'comprehensible input' (Krashen, 1985) in the target language (L2). With the advent of the 'Communicative Language Teaching' approach (CLT) in the late seventies, the use of the mother tongue in monolingual contexts has since been somewhat frowned upon in EFL classrooms and has excited rather negative attitudes in the SLA literature as well as a certain amount of guilt on the part of practising teachers (Ferrer, 2005:1). L1 use in language teaching has been variously described as the 'skeleton in the closet' (Prodromou, 2000:1) or as a 'bone of contention' (Gabrielatos, 2001); even learners, especially the more advanced ones, seem to reject translation or resorting to their L1 explicitly in the language classroom, ${ }^{2}$ maybe as a result of constantly being reminded how ineffective or dangerous it can be as a learning technique by their conscientious teachers. This is especially true considering the recent rise in popularity of Content and Language Integrated Learning (CLIL) and the promotion of acquisition contexts by means of content-based instruction in a range of subjects in the L2 in formal secondary educational settings. Additionally, the activity of translation has usually been treated either as a text-based discipline in itself rather than as a learning resource at sentential level, or for evaluation purposes in order to test translating ability rather than develop linguistic competence.

However, the use of L1 and translation activities in language teaching have enjoyed renewed attention (e.g. Ferrer, 2005; Deller and Rinvolucri, 2002; Atkinson, 1993, 1987; Auerbach, 1993). As Rinvolucri so succinctly reminds us in a recent publication, "the mother tongue is the womb from which the second language is born" (Deller and Rinvolucri, 2002:4), a metaphor which clearly highlights the more favourable facilitating role currently attributed to translation and the use of the mother tongue in EFL contexts. Yet, it should be taken into account that such an L1-based methodological approach is principally promoted by practising teachers rather than supported by empirically based studies of linguistic achievement. This is particularly relevant if we remember that it is also a reality that L1 use, albeit surreptitious, is frequent in the language learning classroom. It has been suggested that the L1 might be included in limited doses, simply for procedural or managerial aspects such as setting up tasks, monitoring group and pair work, giving instructions or checking comprehension (e.g. Atkinson, 1993; 1987). Nevertheless, the majority of learning activities in contemporary EFL

\footnotetext{
${ }^{2}$ See Prodromou's article on the British Council 'Teaching English' website for an example survey (http:/ /www.teachingenglish.org.uk/think/methodology/mother_tongue.shtml).
} 
contexts are still conscientiously conducted in the target language in order to maximise exposure, exploit acquisition possibilities and create opportunities for both controlled and creative use.

It is our belief that a more open-minded approach to using the mother tongue could be adopted in order to encourage learners to focus on similarities and differences between their first language and the target language under study rather than just using it as a managerial aid. The use of L1 has also been promoted for certain procedures such as explaining difficult concepts, checking comprehension, raising confidence, explaining the rationale of language learning activities, error analysis, or vocabulary clarification (e.g. Prodromou, 2002). It is our aim here to further explore the value of the judicious use of L1 and translation in monolingual environments as a teaching and learning resource which can greatly enhance the second/ foreign language acquisition process and help learners understand and associate with the target language under study, particularly as a means to help features of input become intake, promote noticing, raise metacognitive awareness, foster guided reflection, and develop both cognitive and metacognitive learning strategies ${ }^{3}$ by means of contrastive analysis techniques and cross-linguistic comparison.

\section{RESEARCH METHODOLOGY}

After many years of strictly following a non-mother tongue policy ourselves, in the present study we decided to investigate the potentially valuable role of L1 use in the monolingual language learning classroom and examine the effect of integrating translation activities as both a conscious cognitive learning strategy and a means of raising metacognitive awareness in our classes with first-year 'English Language I' students at the University of Las Palmas de Gran Canaria. We were particularly interested in our learners' own perceptions of the value of cross-linguistic comparison as an explicit learning technique as it has been demonstrated that contrastive analysis of grammar may be beneficial as a means to highlight similarities and differences between languages in classes where learners all share the same L1 (e.g. Shweers, 1999; Harbord, 1992; Atkinson, 1987; James, 1980). We were also curious to discover our learners' beliefs concerning translation activities and the use of L1 in order to contrast with previous findings (e.g. Prodromou, 2002) particularly since there has been little research so far in this area (Ferrer, 2005:1). How useful do our learners feel the use of the mother tongue and/or translation is as a language learning strategy in a monolingual context?

In order to address these questions, after having explicitly integrated translation activities into our regular teaching sessions with first-year university learners of EFL over the academic year 2005-2006, we administered a questionnaire (see Appendix I) to a total of 25 students $^{4}$ who had received instruction over five hours a week as part of their university studies in 'English Philology' at the University of Las Palmas de Gran Canaria, Canary Islands, Spain

\footnotetext{
${ }^{3}$ For example, Oxford (1990) has included translation as a cognitive strategy in her 64-item language learning strategy framework.

${ }^{4}$ The subjects had been divided into two groups for teaching purposes during the year, but had followed the same syllabus and used the same materials.
} 
and who all have Spanish as their mother tongue apart from one Italian speaker. These subjects were all part of a larger research project investigating language learning strategies and motivational issues, the results of which are still being collated to date. The students' level of English had been formally tested at the beginning of the academic year in October 2005 using the computer-based version of the 'Quick Placement Test' (Oxford University Press, 2001) in conjunction with a free written sample, and it was found that the overwhelming majority were of a late elementary or low intermediate ability $(\mathrm{A} 2 / \mathrm{B} 1)^{5}$, a finding that is also a cause for some concern considering these were university level learners.

We isolated the following language areas as suitable for contrastive analysis work due to differences as well as misleading similarities between these structures in Spanish and English: (i) 'be/get used to' and 'used to'; (ii) future forms; (iii) uses of 'have' (for expressing possession, the dynamic use, as a modal verb of obligation, and as auxiliary in complex verbs forms); (iv) present and past wishes/complaints; and (v) articles and countability. Worksheets and activities were prepared and integrated into normal class sessions, including the dictation of sentences in L1 for simultaneous translation, written translation of both sentences and short texts from Spanish-English and English-Spanish, cross-linguistic comparison, and guided discovery analysis techniques (see Appendix II for a selection of examples). It is relevant to point out here that in the majority of our teaching sessions we had followed a policy of maximum L2 exposure especially in lexically-based areas, strongly recommending the use of monolingual dictionaries and vocabulary recording techniques in L2 such as writing definitions of new lexical items exclusively in English.

\section{RESULtS}

As was described in section 2 above, we employed a questionnaire (Appendix 1) in order to obtain some empirical data related to the use of L1 and translation in an EFL context, the results of which have been gleaned from the answers given by the students to all 20 items presented. These data can be organised into 4 major blocks:

(i) the use of translation in language learning (items 1-6)

(ii) the use of the mother tongue in language learning (items 7-10)

(iii) the use of contrastive analysis between the mother tongue and L2 (items 11-14)

(iv) awareness of language learning techniques (items 15-20)

\subsection{The use of translation in language learning (items 1-6)}

The first item (1a-d) included in this group (Suelo traducir palabras o frases del inglés al español cuando: (a) estudio, (b) trabajo en clase, (c) escucho una canción en inglés, (d) leo un texto en inglés, (e) aprendo vocabulario) addresses different contexts where our learners choose to employ translation as a means to enhance or consolidate their learning. The results are overwhelming in the sense that in all of the areas consulted, this technique is very

\footnotetext{
${ }^{5}$ These levels refer to those established by the Common European Framework of Reference for Languages.
} 
frequent among our students, especially in reading activities and when they listen to songs in English (see Appendix 3 for the full results). In the responses to item 2 (La traducción me ayuda a aprender inglés), we can appreciate the highly positive attitude towards the use of translation that exists in our learning context since $92 \%$ of the students (44\% strongly agree, $48 \%$ agree) seem to believe that translating helps them to learn English more effectively. We also asked our students about whether they found the translation activities which had been carried out during the year useful or not for their language learning processes (item 3: Las actividades de traducción que hemos realizado durante el curso me han resultado útiles), and the results are clear in the sense that $84 \%$ of the students ( $48 \%$ strongly agree, $36 \%$ agree) explicitly claim that these activities have helped them in their learning process. It is interesting to highlight here that despite our careful sensitisation with regard to lexical issues and repeated training in monolingual vocabulary recording techniques, an overwhelming majority (96\%: $36 \%$ strongly agree, $60 \%$ agree) prefer to translate English vocabulary into Spanish (item 4: Traducir palabras o expresiones al español me ayuda a aprender vocabulario). These results confirm the data obtained from item number 1(e), with $16 \%$ of the students often, and $44 \%$ sometimes, translating English vocabulary into Spanish, and $36 \%$ always doing it despite the teachers' better efforts. Similarly, although with a lower percentage of $72 \%$ (28\% strongly agree, $44 \%$ agree), the majority of students find translating English grammatical structures into Spanish useful for their understanding (item 5: La traducción al español me ayuda a comprender estructuras gramaticales), and in total 64\% (16\% strongly agree, $48 \%$ agree) appreciate the teachers' translation of English vocabulary items and grammatical structures in Spanish (item 6: Me resulta útil cuando mi profesora traduce directamente palabras y estructuras en español).

These results are significant in the sense that teachers are very often concerned with the exclusive use of the target language in the classroom and the avoidance of the mother tongue, which is generally considered as "acting counter to the principles of good teaching" (Ferrer, 2005:1), hence they encourage students to avoid using L1 by all means. However, and it could be said that fortunately for the purposes of this study, in spite of teachers' efforts to the contrary students are not totally influenced by this trend and feel that translation is a useful strategy in their learning process. This view is more in line with those like Gabrielatos (2001:1) who encourage both teachers and students to use the mother tongue in the classroom and not to treat this use "as a sin".

\subsection{The use of the mother tongue in language learning (items $7-10$ )}

The items grouped under (ii) deal with more specific aspects of the use of the mother tongue in the language learning environment. In the responses to item 7 (Encuentro útiles las explicaciones de estructuras inglesas en español) $76 \%$ in total (20\% strongly agree, 56\% agree) appreciate the teachers' explanations of English grammatical structures in Spanish. However, the use of the mother tongue for managerial processes, such as instruction giving, is not so often preferred (item 8: A veces necesito que la profesora o algún compañero me explique en español lo que tengo que hacer en clase cuando hacemos actividades en inglés), since although $40 \%$ in total report that they agree with the statement (20\% strongly agree, $20 \%$ agree), we should point out that in fact $40 \%$ of the students strongly disagree. This is an interesting result because it contradicts the general opinion cited before (e.g. Atkinson, 
1993) that the mother tongue may be more useful in the procedural stages or managerial functions of a class as for example in setting up pair and group activities. As a matter of fact, we believe that the kind of language used in these procedural tasks is simple (mainly imperatives), brief, and repetitive because the instructions are very often the same, so students get used to this kind of language rapidly and can understand it without any problems.

In addition, the figures corresponding to the use of the mother tongue by students as a way of checking they have understood something they have read or heard (item 9: Suelo utilizar el español para confirmar algo que he comprendido, oído o leído) are considerably high (16\% strongly agree, $48 \%$ agree), which indicates that they are still far too reliant on their mother tongue for confirmation and do not really trust in their linguistic capacities in English. Finally, there does not appear to be a marked tendency towards the use of L1 or L2 by our students in order to talk about their language learning progress with their teachers (item 10: Encuentro necesario hablar en español con mi profesora sobre mi progreso en inglés). Thus, although 48\% (20\% strongly agree, $28 \%$ agree) of the students prefer to use Spanish in order to talk about their progress, the other half of the group either do not really have a special preference as to which language they prefer $(24 \%)$ or definitely confirm that they prefer to always use the second language (28\%), that is if they ever participate in this activity at all.

An initial conclusion which could be drawn from the results obtained from this preliminary analysis of the use of the mother tongue in second language learning is that L1 seems to be preferred for linguistic or lexical content rather than metacognitive, social, or affective aspects, which may be due to a lack of awareness or maturity on the part of students.

\subsection{The use of contrastive analysis between the mother tongue and L2 (items 11-14)}

Within the third group, items related to contrastive analysis and cross-linguistic comparison between the mother tongue and L2 were questioned. In general, it can be claimed that although students feel in $88 \%$ of the cases (56\% strongly agree, $32 \%$ agree) that it is necessary for their language learning process to be aware of the differences and similarities between the mother tongue and the L2 (item 14: Creo que es necesario ser consciente de las similitudes $y$ diferencias entre el inglés y el español), almost half of the students either disagree or do not have an opinion as to whether contrastive analysis will help them in their comprehension of the structures under concern (item 11: Comparar las estructuras gramaticales en español y en inglés me ayuda a comprenderlas) or in the grammatical formation of such constructions (item 12: Ver estructuras traducidas al español me ayuda a asimilar la construcción de oraciones en inglés (cómo se forman, el orden de los componentes, los elementos gramaticales implicados, etc.)). Similarly, only $48 \%$ of the students (16\% strongly agree, $32 \%$ agree) claim that contrastive analysis between the two languages helps them avoid making errors which could be derived from the transfer of their mother tongue (item 13: Analizar las estructuras gramaticales en ambas lenguas me ayuda a no cometer errores derivados de la transferencia de mi lengua materna), and surprisingly $40 \%$ of the students do not have a clear opinion about this matter. It seems that there is more research to be done in this area; it could be the case that these lower-than-expected results are due to a lack of awareness on the part of the subjects as regards the rationale behind the translation activities they have participated in. 


\subsection{Awareness of language learning techniques (items 15-20)}

The fourth group of items addresses learners' awareness of the use of L1 or L2 and translation as learning techniques. With regards to the use of L1 or L2 in the language learning classroom, in total $72 \%$ of the students surveyed (36\% strongly agree, $36 \%$ agree) feel that the lessons should entirely be given in English (item 18: Prefiero que las clases sean totalmente en inglés), with no student disagreeing about this matter and $24 \%$ not giving an opinion. Those students who prefer to have their lessons totally in English seem to realise the value of the target language environment for acquisition potential, showing awareness on a metacognitive level. Nevertheless, despite this marked predisposition towards preferring their lessons in English, only $40 \%$ of the students claim that they do not try to resort to Spanish (item 19: Intento no recurrir nunca al español), which implies that they are, in fact, falling back on their L1 more than they will perhaps admit in order to learn more effectively. In addition, almost half of the students surveyed (48\%) admit that they frequently use their mother tongue when they are working in pairs or groups (item 16: Hablo en español cuando trabajamos en parejas o grupos), and $28 \%$ of these students do not give their opinion about this matter, probably due to the aforementioned feeling of guilt or shame associated with admitting to using the mother tongue, especially because they are aware of the teachers' efforts in training and encouraging them to use the L2 in all speaking activities.

Although we explicitly included translation activities in our instructional practice as a means to investigate their effectiveness, we also addressed the ways in which our learners resort to translation indiscriminately as a non-judicious and automatised language learning resource. For example, item 15 (Suelo traducir directamente del español al inglés cuando hablo) asks students whether they translate directly from Spanish into English when they speak in English, and the result is positive in the sense that $52 \%$ of the students totally disagree with this practice and only $28 \%$ of the students admit that they often do it. As for writing skills (item 17: Cuando escribo en inglés pienso las frases en español primero), the result is also encouraging in the sense that $44 \%$ of the students are aware that this is not a recommended strategy in order to develop their foreign language writing abilities, but there is a still a high number of students (40\%) who, probably knowing that it is not advisable, admit that they often do it. However, the use of translation from Spanish into English (item 20: Suelo traducir oraciones del español al inglés) seems to be more frequent than our subjects admitted in the previous two items since in total 52\% reported translating from Spanish to English regularly, with $32 \%$ admitting not using it as such.

\section{Conclusions}

Despite the widely held opinion in many teaching and SLA research contexts that attention to L1 may hinder progress in language learning, a belief that has undoubtedly been ingrained over the years into our learners, we hope to have demonstrated in this brief study that the use of L1 and translation seem to, in fact, enhance second language acquisition processes. The learners in our study appear to show a favourable response to the translation activities and the judicious use of mother tongue in the same way as findings reported by Ferrer (2005) and Shweers (1999) in contrast to the more negative reactions with advanced learners described 
by Prodromou (2002). However, it is interesting to note that our learners do not seem to perceive the value of cross-linguistic comparison. Although this might be considered a rather disappointing result for the purposes of our study, we feel that this result might be due to the lack of awareness of our learners with regard to the benefits of contrasting structures between L1 and L2. We intend to readdress this matter in further research, so that our students appreciate the rationale behind this particular technique.

Translation activities focusing on areas of similarity and difference between languages might, in fact, enjoy a more favourable outlook. The judicious use of the mother tongue and translation as a teaching tool could be advisable as a means to increase knowledge of language systems in order to help learners make useful comparisons between languages; it is a wellknown fact that students do this all the time mentally so it seems logical to make it explicit as a means to promote the noticing of features of language input for improving acquisition potential. We should still bear in mind, however, the role of maximised target language input in monolingual contexts and the fact that translation techniques might be more justifiable in relation to grammatical aspects rather than lexical recording or learning techniques which maybe only further advocate the fallacy of assuming a direct equivalence of words, phrases or concepts between languages. ${ }^{6}$ As Ferrer has posited (2005:6), raising awareness of the value of comparisons between languages in regular EFL instruction contributes to promoting second language acquisition processes by enabling learners to "notice the 'gap' between their inner grammars and the target language and ultimately, through constant hypothesis testing, achieve higher levels of grammatical as well as communicative competence." Prodromou reminds us that there is much potential for using the mother tongue in language learning contexts rather than abusing it (Deller and Rinvolucri 2002:5). We hope to have shown here that judiciously resorting to L1 in the EFL classroom may be in fact more a help than a hindrance.

\section{Bibliography}

Atkinson, D. (1993). Teaching Monolingual Classes. Harlow: Longman.

Atkinson, D. (1987). "The mother tongue in the classroom: a neglected resource?", in ELT Journal, 41, 4: 241-47.

Auerbach, E. (1993). "Reexamining English only in the ESL classroom?”, in TESOL Quarterly, 27, 1:9-32.

Deller, S. and Rinvolucri, M. (2002). Using the Mother Tongue: Making the Most of the Learner's Language. London: Delta Publishing.

Ferrer, V. (2005). "The use of the mother tongue in the classroom: cross-linguistic comparisons, noticing and explicit knowledge." (Online: http://www.teachenglish worldwide.com/ Articles.htm.).

\footnotetext{
${ }^{6}$ We have also found that translation can also be used to help learners realise that there is not always a one-to-one correspondence between languages (e.g. the use of 'make' and 'do' in English as compared to 'hacer' in Spanish) and that seemingly common items such as 'beer' and 'cerveza' are culturally loaded. See Gabrielatos (1998) for interesting practical examples and activities based on similarities between Greek and English.
} 
Gabrielatos, C. (2001). "L1 use in ELT: not a skeleton, but a bone of contention", in Bridges, 6: 33-35. (Online: http://www.thrace-net.gr/bridges/6/).

Gabrielatos, C. (1998). "Translation impossibilities: problems and opportunities for TEFL", in TESOL Greece Newsletter, 60:21-24. (Online: http://www.gabrielatos.com / TranslationImpossibilities).

Harbord, J . (1992). "The use of the mother tongue in the classroom.", in ELT Journal, 46, 4: 35055.

James, C. (1980). Contrastive Analysis. Harlow: Longman.

Krashen, S. (1988). Second Language Acquisition and Second Language Learning. London: Prentice Hall International.

Krashen, S. (1985). The Input Hypothesis: Issues and Implications. Harlow: Longman.

Oxford, R. (1990). Language Learning Strategies: What Every Teacher Should Know. New York: Newbury House Publishers.

Prodromou, L. (2002). "The role of the mother tongue in the classroom", in IATEFL ISSUES: 68.

Prodromou, L. (2000). "From mother tongue to other tongue", in TESOL Greece Newsletter, 67. (Online: http://www.thracenet.gr/bridges/bridges5/).

Richards, J.C. and T.S. Rogers. (2001) (1986). Approaches and Methods in Language Teaching $\left(2^{\text {nd }}\right.$ Ed.). Cambridge: Cambridge University Press.

Schweers, C. W. Jr. (1999). "Using L1 in the L2 Classroom", in English Teaching Forum, 37, 2. (Online: http://exchanges.state.gov/forum/vols/vol37/no2/p6.html).

Software:

'Quick Placement Test' (50 use CD ROM Pack) (2001) in collaboration with the University of Cambridge ESOL Examinations (formerly UCLES). Oxford: Oxford University Press. User manual: ISBN: 0-19-453583-5; CD ROM: ISBN: 0-19-453578-9. 


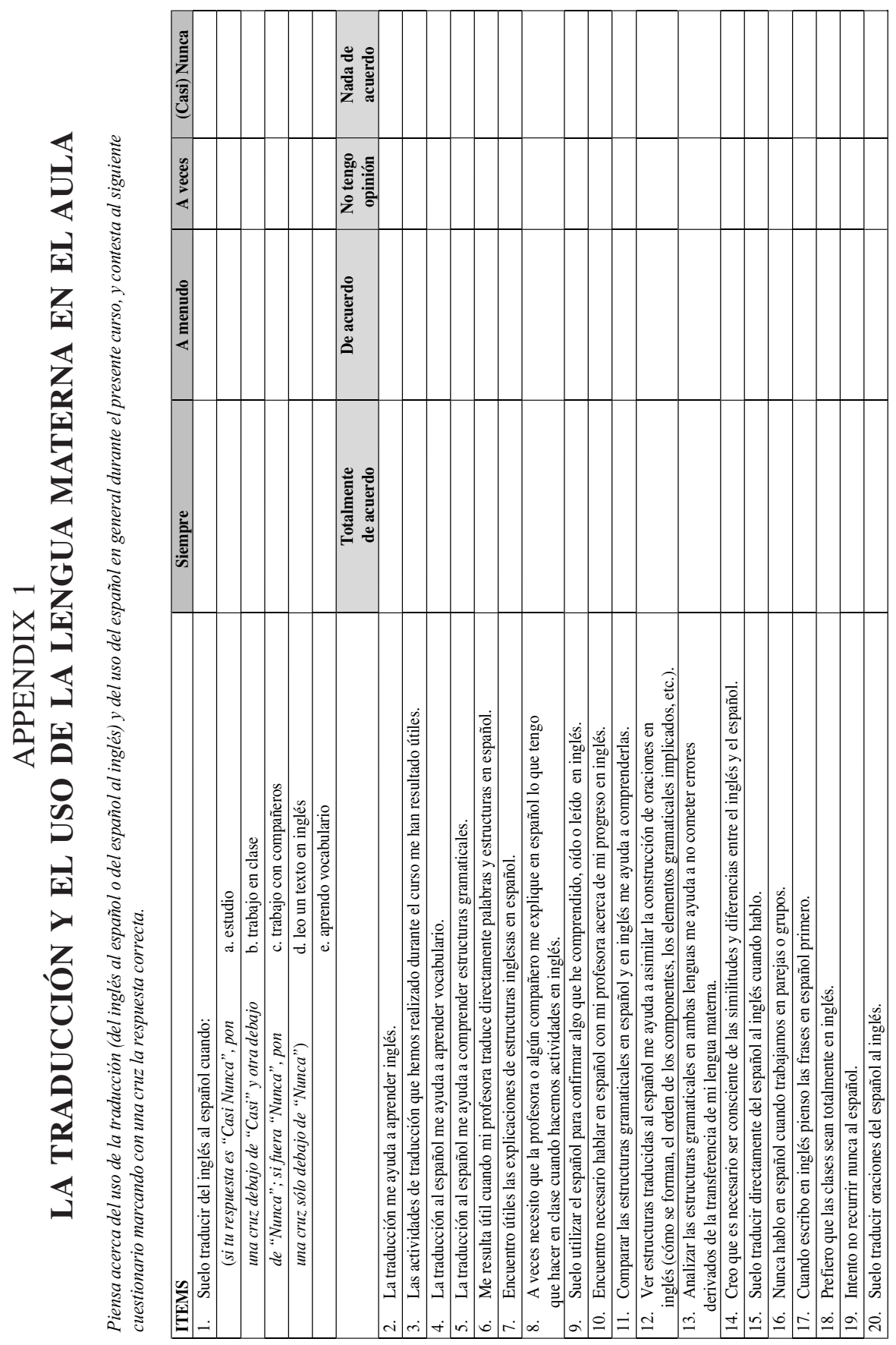




\section{APPENDIX 2}

\section{(i) 'be/get used to' and 'used to'}

A. Fill in the table below by translating the Spanish expressions into English and explaining their use:

\begin{tabular}{|l|l|l|}
\hline SPANISH & ENGLISH & USE \\
\hline Yo suelo $\ldots$ & & \\
\hline Yo solía... & & \\
\hline $\begin{array}{l}\text { Estoy acostumbrado } \\
\text { a viajar }\end{array}$ & & \\
\hline $\begin{array}{l}\text { Me estoy acostumbrando } \\
\text { a viajar }\end{array}$ & & \\
\hline
\end{tabular}

B. Translate the Spanish sentences below into English. Pay special attention to the words underlined.

1. Susan solía cocinar mucho cuando vivía en Italia.

2. No estoy acostumbrada a llevar lentillas, me resulta extraño.

3. ¿Crees que podría' acostumbrarme a hablar inglés en clase? Es una situación nueva para mí y me resulta difícil.

4. Mis hermanas suelen leer comics en la cama.

5. Al principio fue difícil, pero finalmente me acostumbré a conducir por la izquierda.

6. La gente está acostumbrada a hablar por los móviles en todos sitios. Es algo completamente normal.

7. A: "La primera vez que visité Leeds lo pasé mal porque no estaba acostumbrada al acento del norte y casi no entendía una palabra."

B: "Y ahora, ¿te has acostumbrado al acento?

A: "Sí, me he acostumbrado y de hecho me encanta."

\section{(ii) Future forms}

Dictation: Translate the following Spanish sentences and write them down in English:

1. Voy al cine este miércoles por la tarde.

2. Quizá vaya de compras esta tarde.

3. ¡Cuidado! Esa niña se va a caer.

4. Creo que terminaré mis estudios el año que viene.

5. No puedo comer contigo hoy porque almuerzo en casa de mi madre.

6. El avión sale esta noche a las 11 . 
(iii) The verb 'have'

A. USES OF "HAVE"
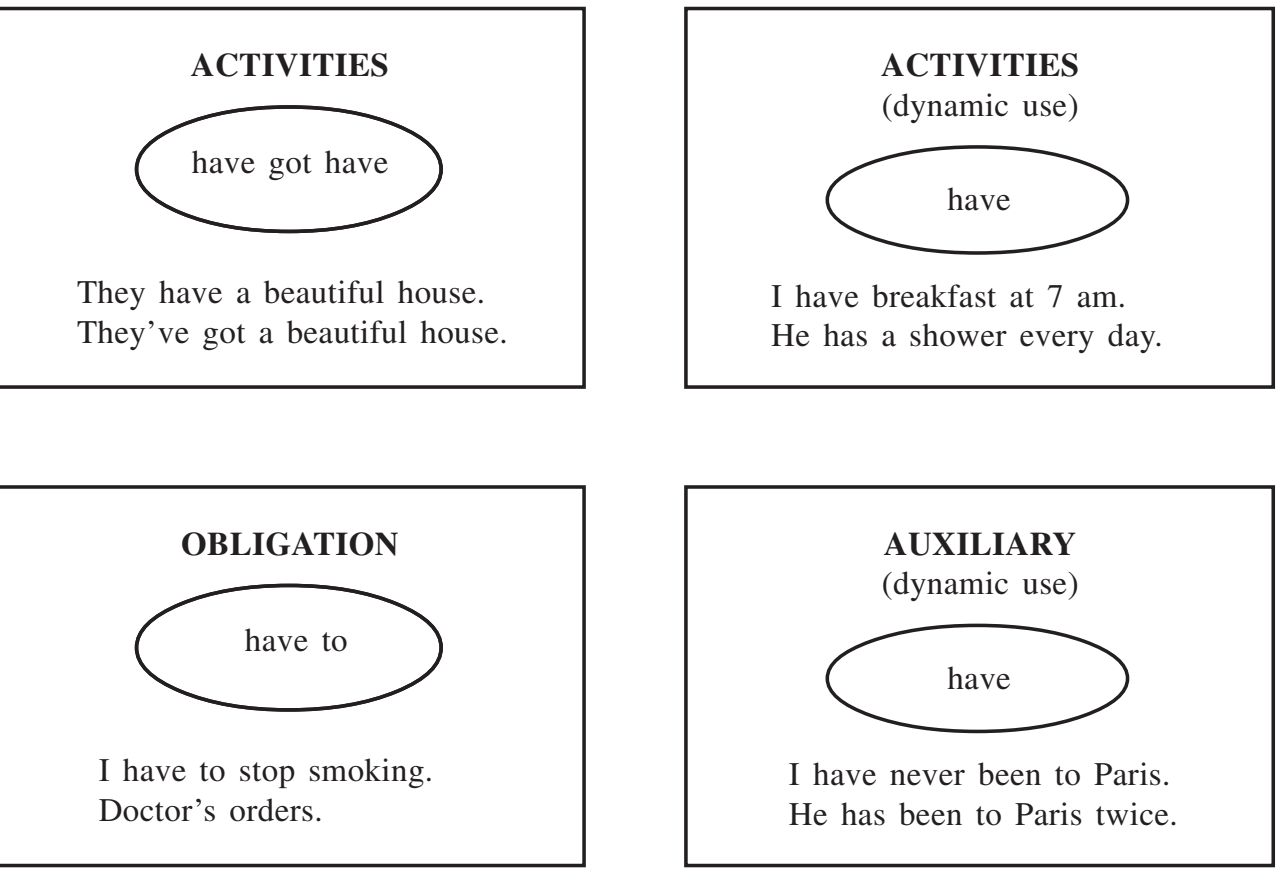

\section{NEGATIVE FORM}

HAVE GOT: I haven't got a car. / He hasn't got a bike.

HAVE: I don't have a car. / He doesn't have a bike. (possession)

He doesn't have breakfast at home. (activity)

I haven't eaten snails / I've never eaten snails (present perfect)

HAVE TO: You don't have to wear a uniform.

\section{INTERROGATIVE FORM}

HAVE GOT: Have you got a car? Yes, I have. / No, I haven't.

Has he got a bike? Yes, he has. /No, he hasn't.

HAVE: Do you have a car? Yes, I do. /No, I don't. (possession)

Does he have a bike? Yes, he does. / No, he doesn't. (possession)

Does he have breakfast at $7 \mathrm{am}$ ?

Yes, he does. / No, he doesn't. (activity)

Has he eaten snails? Yes, he has. / No, he hasn't. (present perfect)

HAVE TO: Do you have to travel on business? Yes, I do. / No, I don't. 
THE PAST $\rightarrow$ HAD for possession, activities, obligation and the past perfect

Possession: I/He/They had a car; I/He/We didn't have a car; Did she have a bike?

Activities: I/She/We had breakfast; I/We/She didn't have lunch.

Did they have dinner at home?

Obligation: He had to wear a tie; He didn't have to wear a tie.

Did he have to wear a tie?

Past perfect: He had eaten snails before; He hadn't eaten snails before;

Had he eaten snails before?

B. Complete the following sentences with an appropriate form of the verb have :

1. Mark is 21 and he fair hair and blue eyes. He two sisters but he any brothers. He always lunch with them at the weekends.

2. How many times (you/take) your driving test?

3. - This book is very boring.

- Why (read) it?

- Because I a literature exam next week.

4. Tim is a good photographer. What kind of camera (he)?

5. (you/ever/walk) more than $35 \mathrm{kms}$ ?

6. They (not / see) Tom since he left home this morning.

7. - What's the matter with Pete?

- I don't know. The doctor says that he three days. (stay) in bed for

8. (John/ever/ travel) in a canoe?

9. - I really must go home. I (get up) early tomorrow.

- What about your husband? (get up) early too?

- No, he . He can stay in bed a bit longer.

10. I (not / be) here before but I really like it.

C. Translate the following Spanish sentences into English:

1. ¿Tienes coche?

2. ¿Cuántos hermanos tienes?

3. No tengo dinero. 
4. Cuando era niña, yo tenía muchos juguetes.

5. ¿Tuviste problemas para hacer este ejercicio? No, no tuve ningún problema.

6. Es una fiesta formal, pero los hombres no tienen que llevar chaqueta.

7. Ahora estoy desayunando, y después me voy a duchar. Te llamo cuando haya acabado.

8. Él nunca ha vivido en el extranjero.

9. Cuando llegué, mis amigas ya le habían dado los regalos a Susan.

\section{(iv) Wishes}

Translate the following Spanish sentences into English:

1. Ojalá tuviese suficiente dinero para siempre ir a la última moda.

2. Ojalá siempre pudiese llevar vaqueros de marca.

3. Ojalá supiera cómo comprar ropa en Internet.

4. Ojalá no me hubiese comprado esta marca de ropa. No tiene buena relación calidad precio.

5. Ojalá me hubiese puesto las playeras y no estos zapatos de tacón alto.

6. Ojalá Susan no le hubiese dicho a mi novio lo que realmente ocurrió.

7. Ojalá no me hubiese comprado estos pantalones. ¡No me quedan bien!

8. Ojalá esos niños dejaran de gritar; me están volviendo loca.

9. Ojalá mi hermano mayor ayudara más en las tareas de la casa.

10. Ojalá me llamaras por teléfono más a menudo.

\section{(v) Articles and countability}

A. Translate the first two paragraphs from the text "Why men don't iron" (English File Upper-Intermediate, Oxford University Press, 2001: 60) into Spanish:

During the last fifty years psychologists have made us believe that differences between men and women are mainly the result of traditional social 'conditioning', i.e. the way we are brought up. According to this theory women can be trained to do jobs that men traditionally do, and men can and should become more domesticated. This so-called 'new man' should be in touch with his 'feminine side', more communicative and emotional, and should do the ironing.

But two new books say that, according to recent scientific research, gender differences exist because men's and women's brains work completely differently and their biological differences mean that they can never think of behave in the same way.

Once you have translated the text into Spanish, underline all the examples of definite and indefinite articles both in the English and in the Spanish texts, and draw some conclusions about the use of articles in English.

\section{B. Translate the following Spanish sentences into English:}

1. Los ordenadores japoneses son muy caros.

2. Los gatos son animales domésticos. 
3. Los médicos necesitan años de preparación.

4. Me gusta la mantequilla.

5. Hay unos sándwiches en el plato.

6. ¿Cuánto cuestan las manzanas? Un euro el kilo.

7. ¿A qué se dedica Tom? Es arquitecto.

8. Me voy a la cama, tengo dolor de cabeza.

9. EL inglés es más fácil que el español.

10. ¿Dónde está tu hijo? Ha ido al colegio.

11. ¿Dónde está tu hijo? Está en el colegio.

12. El lago Windermere está en el distrito de los Lagos.

13. Vivo en Canarias.

14. Mis abuelos viven en la calle León y Castillo.

15. Mi hermana compró tres muebles en las rebajas.

16. Siempre recordaré los consejos que me dio mi abuela.

17. Mi hermano está en Londres. ¡Está haciendo un tiempo estupendo! 


\section{APPENDIX 3}

\begin{tabular}{|l|c|c|c|c|c|}
\hline ITEM 1 & (a) Estudio & (b) En clase & (c) Canciones & (d) Leo & (e) Vocabulario \\
\hline Siempre & $24 \%$ & $12 \%$ & $32 \%$ & $12 \%$ & $36 \%$ \\
\hline A menudo & $24 \%$ & $40 \%$ & $28 \%$ & $48 \%$ & $16 \%$ \\
\hline A veces & $44 \%$ & $40 \%$ & $24 \%$ & $32 \%$ & $44 \%$ \\
\hline Casi nunca & $4 \%$ & $4 \%$ & $0 \%$ & $0 \%$ & $0 \%$ \\
\hline Nunca & $4 \%$ & $4 \%$ & $16 \%$ & $8 \%$ & $4 \%$ \\
\hline
\end{tabular}

\begin{tabular}{|l|c|}
\hline ITEM 2 & PERCENTAGE \\
\hline Totalmente de acuerdo & $44 \%$ \\
\hline De acuerdo & $48 \%$ \\
\hline No tengo opinión & $4 \%$ \\
\hline Nada de acuerdo & $4 \%$ \\
\hline
\end{tabular}

\begin{tabular}{|l|c|}
\hline ITEM 3 & PERCENTAGE \\
\hline Totalmente de acuerdo & $48 \%$ \\
\hline De acuerdo & $36 \%$ \\
\hline No tengo opinión & $8 \%$ \\
\hline Nada de acuerdo & $0 \%$ \\
\hline Vacía & $8 \%$ \\
\hline
\end{tabular}

\begin{tabular}{|l|c|}
\hline ITEM 4 & PERCENTAGE \\
\hline Totalmente de acuerdo & $36 \%$ \\
\hline De acuerdo & $60 \%$ \\
\hline No tengo opinión & $0 \%$ \\
\hline Nada de acuerdo & $4 \%$ \\
\hline
\end{tabular}

\begin{tabular}{|l|c|}
\hline ITEM 5 & PERCENTAGE \\
\hline Totalmente de acuerdo & $28 \%$ \\
\hline De acuerdo & $44 \%$ \\
\hline No tengo opinión & $16 \%$ \\
\hline Nada de acuerdo & $12 \%$ \\
\hline
\end{tabular}

\begin{tabular}{|l|c|}
\hline ITEM 6 & PERCENTAGE \\
\hline Totalmente de acuerdo & $16 \%$ \\
\hline De acuerdo & $48 \%$ \\
\hline No tengo opinión & $20 \%$ \\
\hline Nada de acuerdo & $16 \%$ \\
\hline
\end{tabular}

\begin{tabular}{|l|c|}
\hline ITEM 7 & PERCENTAGE \\
\hline Totalmente de acuerdo & $20 \%$ \\
\hline De acuerdo & $56 \%$ \\
\hline No tengo opinión & $16 \%$ \\
\hline Nada de acuerdo & $8 \%$ \\
\hline
\end{tabular}

\begin{tabular}{|l|c|}
\hline ITEM 8 & PERCENTAGE \\
\hline Totalmente de acuerdo & $20 \%$ \\
\hline De acuerdo & $20 \%$ \\
\hline No tengo opinión & $16 \%$ \\
\hline Nada de acuerdo & $40 \%$ \\
\hline Vacía & $4 \%$ \\
\hline
\end{tabular}

\begin{tabular}{|c|c|}
\hline ITEM 9 & PERCENTAGE \\
\hline Totalmente de acuerdo & $16 \%$ \\
\hline De acuerdo & $48 \%$ \\
\hline No tengo opinión & $12 \%$ \\
\hline Nada de acuerdo & $24 \%$ \\
\hline ITEM 10 & PERCENTAGE \\
\hline Totalmente de acuerdo & $20 \%$ \\
\hline De acuerdo & $28 \%$ \\
\hline No tengo opinión & $24 \%$ \\
\hline Nada de acuerdo & $28 \%$ \\
\hline
\end{tabular}

\begin{tabular}{|l|c|}
\hline ITEM 11 & PERCENTAGE \\
\hline Totalmente de acuerdo & $24 \%$ \\
\hline De acuerdo & $28 \%$ \\
\hline No tengo opinión & $20 \%$ \\
\hline Nada de acuerdo & $20 \%$ \\
\hline Vacía & $8 \%$ \\
\hline
\end{tabular}

\begin{tabular}{|l|c|}
\hline ITEM 12 & PERCENTAGE \\
\hline Totalmente de acuerdo & $8 \%$ \\
\hline De acuerdo & $48 \%$ \\
\hline No tengo opinión & $20 \%$ \\
\hline Nada de acuerdo & $24 \%$ \\
\hline
\end{tabular}

\begin{tabular}{|l|c|}
\hline ITEM 13 & PERCENTAGE \\
\hline Totalmente de acuerdo & $16 \%$ \\
\hline De acuerdo & $32 \%$ \\
\hline No tengo opinión & $40 \%$ \\
\hline Nada de acuerdo & $12 \%$ \\
\hline
\end{tabular}

\begin{tabular}{|l|c|}
\hline ITEM 14 & PERCENTAGE \\
\hline Totalmente de acuerdo & $56 \%$ \\
\hline De acuerdo & $32 \%$ \\
\hline No tengo opinión & $12 \%$ \\
\hline Nada de acuerdo & $0 \%$ \\
\hline
\end{tabular}

\begin{tabular}{|l|c|}
\hline ITEM 15 & PERCENTAGE \\
\hline Totalmente de acuerdo & $4 \%$ \\
\hline De acuerdo & $24 \%$ \\
\hline No tengo opinión & $20 \%$ \\
\hline Nada de acuerdo & $52 \%$ \\
\hline Vacía & $8 \%$ \\
\hline
\end{tabular}




\begin{tabular}{|l|c|}
\hline ITEM 16 & PERCENTAGE \\
\hline Totalmente de acuerdo & $8 \%$ \\
\hline De acuerdo & $40 \%$ \\
\hline No tengo opinión & $28 \%$ \\
\hline Nada de acuerdo & $24 \%$ \\
\hline
\end{tabular}

\begin{tabular}{|l|c|}
\hline ITEM 17 & PERCENTAGE \\
\hline Totalmente de acuerdo & $12 \%$ \\
\hline De acuerdo & $28 \%$ \\
\hline No tengo opinión & $16 \%$ \\
\hline Nada de acuerdo & $44 \%$ \\
\hline \multicolumn{2}{|c|}{} \\
\hline ITEM 18 & PERCENTAGE \\
\hline Totalmente de acuerdo & $36 \%$ \\
\hline De acuerdo & $36 \%$ \\
\hline No tengo opinión & $24 \%$ \\
\hline Nada de acuerdo & $0 \%$ \\
\hline Vacía & $4 \%$ \\
\hline
\end{tabular}

\begin{tabular}{|c|c|}
\hline ITEM 19 & PERCENTAGE \\
\hline Totalmente de acuerdo & $24 \%$ \\
\hline De acuerdo & $16 \%$ \\
\hline No tengo opinión & $32 \%$ \\
\hline Nada de acuerdo & $24 \%$ \\
\hline Vacía & $4 \%$ \\
\hline ITEM 20 & PERCENTAGE \\
\hline Totalmente de acuerdo & $32 \%$ \\
\hline De acuerdo & $20 \%$ \\
\hline No tengo opinión & $16 \%$ \\
\hline Nada de acuerdo & $32 \%$ \\
\hline
\end{tabular}

